\title{
Peran Nazhir Dalam Perlindungan Harta Wakaf
}

\section{Nazhir's Role In The Protectionof Waqf Property}

\author{
Nilda Susilawati ${ }^{1}$ Ita Guspita ${ }^{2}$, Dedy Novriadi ${ }^{3}$ \\ ${ }^{1,2}$ Fakultas Ekonomi dan Bisnis Islam IAIN Bengkulu, ${ }^{3} \mathrm{FAI}$ Universitas Muhammadiyah Bengkulu \\ 1nilda79@iainbengkulu.ac.id,2itaguspita@gmail.com,33dedynovriadi@umb.ac.id
}

Manuscript received 31 Maret 2021, processed 01 April 2021, published 30 Juni 2021

\begin{abstract}
Nazhir has a big role in protecting waqf property. Assets that are not managed properly will cause the assets to be destroyed or can be taken back by the wakif's heirs. Nazhir is required to administer waqf assets so that waqf assets are protected and can be used for the benefit of the people. This research was conducted with the aim of knowing the role of Nazhir in North Kaur in protecting waqf property. The research was conducted using a qualitative approach with data collection methods through observation, interviews and documentation. Then do data analysis and draw conclusions. The results showed that some Nazhirs had not yet carried out the task of administering, developing and protecting waqf assets through making waqf pledge deeds. This is due to Nazhir's lack of knowledge and understanding of his duties and functions in managing waqf assets.
\end{abstract}

Keywords: Role of Naz̧bir, Asset Waqf

Abstrak: Nazhir memiliki peran yang besar dalam memberikan perlidungan terhadap harta wakaf. Harta yang tidak dikelola dengan baik, akan menyebabkan harta menjadi musnah atau dapat diambil kembali oleh ahli waris wakif. Nazhir diharuskan melakukan pengadmistrasian harta wakaf agar harta wakaf terlindungi dan dapat dimanfaatkan untuk kemaslahatan umat. Penelitian ini dilakukan dengan tujuan untuk mengengatahui peran nazhir di Kaur Utara dalam melindungi harta wakaf, Penelitian dilakukan dengan pendekatan kualitatif dengan metode pengumpulan data melalui observasi, wawancara dan dokumentasi. Kemudian dilakukan analisis data dan mengambil kesimpulan. Hasil penelitian menunjukkan bahwa sebagian nazhir belum melakukan tugas pengadministrasian, pengembangan dan perlindungan harta wakaf melalui pembuatan akta ikrar wakaf. Hal ini dikarenakan kurangnya pengetahuan dan pemahaman nazhir akan tugas dan fungsinya dalam mengelola harta wakaf.

Kata Kunci: Peran Nazhir, Harta Wakaf

\section{PENDAHULUAN}

Indonesia memiliki potensi harta wakaf terutama tanah terluas di dunia, yaitu sekitar $440.512,89$ ha. Orientasi pengembangan wakaf properti masih didominasi untuk kepentingan keagamaan (masjid dan mushalla) sebesar 73\%; untuk sarana pendidikan sekitar 13,3\%, dan sisanya digunakan untuk sarana sosial seperti kuburan dan tujuan sosial lainnya. Jika aset wakaf dikembangkan secara produktif, potensinya mencapai sekitar 19,4\% dari Produk Domestik Bruto (PDB). Dengan asumsi bila umat muslim Indonesia berwakaf uang Rp10.000 per bulan, maka dana terkumpul bisa mencapai sekitar Rp197 miliar per bulan (Rp2,36 triliun per tahun) hingga Rp985,01 miliar per bulan (Rp11,82 triliun per tahun). (Afdi, 2017: 1-48)

Potensi zakat luar biasa dimiliki oleh umat muslim di Indonesia, namun potensi itu belum dipelihara secara baik, karena nazhir memiliki peran yang sangat besar dalam menjaga, memelihara dan memanfaatkan harta wakaf. Nazhir memiliki peran sentral, karena melalui nazhir harta wakaf dijaga, dipelihara dan 
dikembangkan serta hasilnya disalurkan kepada mauquf alaih. (Rozalinda, 2015)

Wakaf sebagai pemberian seseorang (wakif) agar dimanfaatkan untuk kemaslahatan masyarakat. Pemanfaatan harta wakaf harus sesuai dengan yang diamanahkan wakif. Wakaf dengan makna menahan harta dimaksudkan bahwa harta tersebut berhenti untuk dimanfaatkan secara pribadi dan diganti untuk amal kebaikan sesuai tujuan wakaf. Menghentikan aktivitas pada harta yang semula dapat dijual, transaksi, dihibahkan, dan diwariskan. Maka bila telah diwakafkan harta tersebut hanya dapat dimanfaatkan untuk kepentingan masyarakat bukan kepentingan pribadi atau golongan tertentu. (Abdul Halim, 2005)

Menurut Ash-Shan'ani, nazhir merupakan seseorang yang diberi hak untuk mengelola harta wakaf, dalam konteks mengurus, memelihara dan mengembangkan harta agar tumbuh dengan baik serta mendisribusikannya kepada orang yang berhak menerima manfaatnya. (Departemen Agama RI, 2005)

Wakaf sebagai salah satu instrumen keuangan dalam Islam, memiliki peran besar dalam pengembangan ekonomi dan kemaslahatan umat. Karena itu nazhir memiliki peran dalam pemberdayaan wakaf. Kompetensi nazhir menjadi faktor penunjang dan dipertimbangkan dalam pengelolaan wakaf. Nazhir harus mampu mengelola wakaf agar memiliki nilai tambah dan produktif bagi keberlanjutan maslahah harta wakaf pengelolaan wakaf dapat dikelola secara perseorangan, organisasi maupun badan hukum sebagai potensi zakat di Indonesia. (Prasinanda, 2019)

Nazhir Profesional memiliki tugas pertama, meningkatkan produktifitas harta wakaf agar mencapai hasil yang ideal melalui produktivitas dan investasi. Menekan sebesar mungkin biaya administrasi, mencegah penyimpangan, kerusakan, pencurian dan menyalahgunakan amanah yang telah diberikan.
Kedua, melindungi harta pokok wakaf melalui pemeliharaan dan penjagaan dengan menekan resiko investasi dan melakukan investasi jangka panjang untuk pemeliharaan pokok harta wakaf. Ketiga, memegang teguh amanah wakif dalam hal investasi dan distribusi wakaf. Keempat, melakukan penjelasan kepada wakif dan selalu mendorong untuk melakukan wakaf harta yang baru. (Ridwan, 2012: 91-109)

Setiap kegiatan nazhir mesti mempertimbangkan kesinambungan harta wakaf dan mengalirkan manfaat untuk kepentingan mauqufalaih. Karena itu peran nazhir tidaknya hanya mengalirkan manfaat melalui sedekah tetapi juga memobilisasi aset supaya-upaya pengembangannya.

Setiap kegiatan nazhir terhadap harta wakaf harus dalam pertimbangan kesinambungan harta wakaf dengan mengalirkan manfaatnya untuk kepentingan manqûf 'alaih. Karena itu, peran para nazhir bukan cuma memobilisasi dana wakaf dan langsung membelanjakannya sebagai sedekah, tetapi mewujudkannya terlebih dahulu menjadi aset, lalu mengelolanya secara produktif baru memanfaatkan hasilnya sebagai sedekah. (Tiswarni, 2014: 409-426)

Badan Wakaf Indonesia dalam memberikan sosialisasi dan edukasi kepada para nazhir sebagai bagian dari tugas Badan Wakaf Indonesia dengan melakukan pembinaan kepada nazhir dalam pengelolaan dan pengambngan harta benda wakaf. Bahkan dapat memberhentikan dan mengganti nazhir bila tidak dapat menjalankan tugas nazhir dengan baik. (Aziz, 2017: 35-54)

Menjadi tanggung jawab bersama pemerintah dan Badan Wakaf Indonesia untuk melahirkan nazhir yang profesional dalam pengelolaan wakaf, namun dalam kenyataannya masih terdapat nazhir yang masih mengelola wakaf secara konvesonal.

Penelitian Megawati (2014) yang dilakukan di Pekan Baru bahwa pengelolaan wakaf produktif masih dilakukan secara 
sedehana dan menajemen yang masih tradisonal.

Penelitian yang dilakukan Pusat Bahasa dan Budaya (PBB) UIN Syarif Hidayatullah Jakarta di 11 Propinsi di Indonesia menunjukkan bahwa harta wakaf $77 \%$ diam (77\%) dan hanya $23 \%$ yang produktif. Temuan lainnya bahwa $79 \%$ harta wakaf digunakan untuk pembangunan mesjid dan $79 \%$ berada di daerah pedesaan dan hanya 41\% diperkotaan. Dalam tugas seseorang menjadi nazhir hanya sebagai pekerjaan sampingan tanpa diberi gaji $84 \%$, dan yang fokus mengelola wakaf hanya $16 \%$. Dan $66 \%$ wakaf dikelola secara tradisonal oleh perorangan, dan $16 \%$ wakaf dikelola organisasi profesonal dan 18\% berbadan hukum. Artinya persoalan mendasarkan dalam pengelolaan wakaf adalah harta wakaf yang tidak diproduktifkan dan nazhir yang tidak profesional. (Kasdi, 2014: 213-226), (Wulandari et al., 2019: 295-307)

Dalam Undang-undang 2004 dijelaskan bahwa tugas nazhir yaitu melakukan pengadminstrasian harta wakaf, mengelola dan mengambangkan harta wakaf sebagaimana tujuan, fungsi dan kegunaannya, melakukan pengawasan dan perlindungan serta melaporkan kepada Badan Wakaf Indonesia tentang pelaksanaan dari pemanfaatan harta wakaf.

Banyak konfilk dan sengketa harta wakaf yang timbul akibat kurangnya pemahaman dalam pengelolaan harta wakaf. Penelitian Fadhilah (2011) yang meneliti tentang faktor pemicu sengketa tanah wakaf menurut teori resolusi konflik Ralf Dahrendorf dan strategi penyelesaiannya menemukan bahwa sengketa wakaf disebabkan oleh maslah resources, interest, kebutuhan yang berbeda, velue agama, budaya dan moral.

Persoalan sengketa wakaf banyak ditemui hampir di beberapa daerah di Indonesia. Hal ini terjadi akibat nazhir belum memahami tugasnya dalam pengelolaan harta wakaf, sehingga upaya untuk melindungi harta wakaf dari kemungkinan akan timbulnya sengketa tidak diantisipasi sejak awal. Kondisi ini juga terjadi di Kecamatan Kaur Utara Kabupaten Kaur
Propinsi Bengkulu. Berdasarkan data yang diperolah dari Kantor Urusan Agama Kecamatan Kaur Utara Propinsi Bengkulu bahwa jumlah harta wakaf yang ada berjumlah 18 tanah wakaf berupa fasilitas ibadah seperti mesjid, sekolah/madrasah dan pemakaman umum, hanya 4 harta wakaf yang memiliki akta wakaf. Hal ini menjadi persoalan apabila suatu saat terjadi konflik harta kepemilikan harta wakaf, sementara nazhir tidak memiliki bukti berupa akta ikrar wakaf, maka suatu saat harta wakaf bisa ambil oleh ahli waris, dan ini sangat disayangkan, karena tujuan wakif untuk menyerahkan harta wakaf untuk dimanfaatkan oleh masyarakat dan menjadi amal jariah bagi si wakif. Bila persoalan ini dibiarkan, maka akan banyak tanah wakaf yang tidak dapat dipertahankan akibat tidak memiliki bukti kalau tanah atau bangunan telah diwakafkan, padahal wakif mewakafkan hartanya agar dapat dimanfaatkan oleh masyarakat sebagai ladang amal wakif, bila harta wakaf tidak dilindungi maka akan menyebabkan berkurangnya nilai harta wakaf, bahkan dapat diambil kembali oleh waris yang menginginkan harta tersebut, dengan dalih bahwa harta tersebut tidak memiliki dokumen wakaf yang jelas apabila wakif telah mewakafkan harta yang dimilikinya. Karena itu perlu dilakukan peneltian dan kajian atas persoalan ini untuk mencari solusi agar pemerintah dan Badan Wakaf Indonesia dapat menentukan langkah strategis dalam melakukan sosialisasi dan edukasi kepada masyarakat tentang pengelolaan harta wakaf dan tugas-tugas nazhir dalam melindungi harta wakaf.

Penelitian ini dilakukan dengan tujuan untuk mengatahui gambaran penerapan tugas nazhir di Kecamatan Kaur Utara Kabupaten Kaur Propinsi Bengkulu dalam memberikan perlindungan terhadap harta wakaf yang menjadi salah satu tugas nazir yang diatur dalam undangundang wakaf yaitu melakukan pengadmisitrasian harta wakaf, salah satunya melalui pembuatan akta wakaf, tugas pengelolaan, pengembangan, pengawasan harta 
wakaf dan melaporkan pelaksanaanya kepada Badan Wakaf Indonesia.

\section{METODE PENELITIAN}

Penelitian ini merupakan penelitian deskriptif kualitatif dengan menggambarkan fenomena sosial yang terjadi dalam masyarakat tertang pengelolaan wakaf. Penelitian ini dilakukan di Kecamatan Kaur Utara Kabupaten Kaur Propinsi Bengkulu dengan informan adalah para nazhir yang mengelola harta wakaf berupa tanah wakaf yang dimanfaatkan untuk fasilitas ibadah, pendidikan dan Tempat Pemakaman Umum (TPU).

Data yang digunakan data dalam penelitian ini yaitu data primer berupa data hasil wawancara yang diperoleh langsung dari nazhir yang mengelola harta wakaf. Sedangkan data sekunder diperoleh dari beberapa literatur, dokumen dan catatan yang berkaitan dengan penelitian ini.

Teknik pengumpulan data dilakukan melalui wawancara tidak tersruktur kepada para nazhir yang mengelola tanah wakaf. Wawancara tidak terstruktur bertujuan agar dapat memperoleh data yang lebih mendalam dan lengkap tanpa dibatasi oleh pedoman wawancara. Selain itu juga digunakan observasi dan dokumentasi terkait pengelolaan wakaf.

Data yang telah diperolah kemudian dilakukan analisis data. Teknik analisis data menggunakan konsep Miles dan Huberman bahwa dalam penelitian kualitatif dilakukan secara interaktif dan berlangsung terus menerus pada tiap tahapan penelitian sampai tuntas (Sugiyono, 2014). Kemudian dilakukan reduksi data melalui pemilihan dan penyederhanaan data mentah yang berasal dari catatan-catatan yang ditulis di lapangan. Data diberi kode untuk memudahkan merangkum dan memilah data yang penting.
Penyajian data dilakukan dengan menyusun informasi yang diperoleh secara sistematik, agar lebih efektif dan sederhana dan menyajikan kemungkinan untuk menarik kesimpulan dan menentukan tindakan. Langkah berikutnya dilakukan penyajian data dalam bentuk uraian dan tabel.

Tahap selanjutnya melakukan penarikan kesimpulan dari proses analisis data yaitu dengan membuat kesimpulan dari data dan informasi yang diperoleh dari hasil wawancara dan dokumentasi.

\section{HASIL PENELITIAN DAN PEM B A HA S A N}

Kecamatan Kaur Utara Kabupaten Kaur Propinsi Bengkulu merupakan wilayah yang terletak di sebelah barat bukit barisan. Secara administrasi Kecamatan Kaur berjarak 40 km dari ibukota Kabupaten Kaur, dan 230 $\mathrm{km}$ dari ibukota Propinsi. Dengan luas wilayah daratan 49,80 $\mathrm{km}^{2}$ dan umlah penduduk 8.179 orang terdiri laki-laki 4.175 orang dan perempuan 4.004 orang.

Profesi masyarakat Kecamatan Kaur didominasi sebagai petani, dan sebagian lainnya berprofesi sebagai PNS, TNI/Polri, pedagang, peternak, buruh dan karyawan swasta. Nazhir juga memiliki latar belakang profesi yang berbeda seperti petani, pedagang, PNS, wiraswasta. Begirtu pula dengan profesi utama nazhir yang mengelola wakaf di Kecamatan Kaur Utara berasal dari latar belakang profesi yang berbeda-beda:

Tabel 1

Profesi Nazhir

\begin{tabular}{|c|l|c|}
\hline No & Profesi Nazir & Jumlah \\
\hline 1 & Petani & 10 \\
\hline 2 & PNS/Guru/Kades & 5 \\
\hline 3 & Wiraswasta & 2 \\
\hline
\end{tabular}




\begin{tabular}{|l|l|c|}
\hline 4 & Advokat & 1 \\
\hline
\end{tabular}

Sumber: Olahan Penulis

Berdasarkan tabel di atas terlihat bahwa nazhir memiliki latar belakang profesi mayoritas sebagai petani berjumlah 10 orang, PNS/guru/Kades berjumlah 5 orang, wiraswasta 2 orang dan advokad 1 orang.

Adapun harta yang telah diwakafkan berupa fasilitas mesjid, pendidikan, tanah untuk pemakaman umum dan lahan kosong yang sebagian besar belum memiliki Akta wakaf

Tabel 2

Jenis Harta Wakaf

\begin{tabular}{|l|c|c|}
\hline \multicolumn{1}{|c|}{$\begin{array}{c}\text { Jenis harta } \\
\text { Wakaf }\end{array}$} & Jumlah & Akta Wakaf \\
\hline Mesjid & 12 & 4 \\
\hline Sekolah & 1 & 0 \\
\hline TPU & 4 & 0 \\
\hline $\begin{array}{l}\text { Tanah } \\
\text { Kosong }\end{array}$ & 1 & 0 \\
\hline Jumlah & 18 & 4 \\
\hline
\end{tabular}

Sumber: Olahan Penulis

Dari tabel di atas terlihat bahwa total harta wakaf berjumlah 18 berupa sarana ibadah seperti mesjid, sekolah dan Tempat Pemakaman Umum serta 1 lahan kosong yang b elum dimanfaatkan. Dari total jumlah harta wakaf yang telah memiliki sertifikat wakaf baru 4 tanah wakaf berupa sarana ibadah yaitu mesjid, 8 mesjid belum memiliki akta wakaf. 1 sekolah dan Tempat Pemakaman Umum juga belum memiliki akta wakaf, sedangkan 1 tanah kosong yang akan dibangun mesjid juga belum memiliki akta wakaf. Dengan rincian harta wakaf berupa:
Tabel 3

Harta Wakaf di Kecamatan Kaur Utara

\begin{tabular}{|c|c|c|}
\hline $\begin{array}{c}\text { Jenis Harta } \\
\text { Wakaf }\end{array}$ & $\begin{array}{l}\text { Nama } \\
\text { Harta } \\
\text { Wakaf }\end{array}$ & $\begin{array}{c}\text { Akta } \\
\text { Ikrar } \\
\text { Wakaf }\end{array}$ \\
\hline \multirow[t]{12}{*}{$\begin{array}{l}\text { Sarana } \\
\text { Ibadah }\end{array}$} & $\begin{array}{l}\text { Masjid Al- } \\
\text { Mukminin }\end{array}$ & $\begin{array}{l}\text { Tidak } \\
\text { ada }\end{array}$ \\
\hline & $\begin{array}{l}\text { Masjid Nurul } \\
\text { Hidayah }\end{array}$ & Tidak ada \\
\hline & $\begin{array}{ll}\text { Masjid } & \text { Al- } \\
\text { Ihklas } & \end{array}$ & Tidak ada \\
\hline & \begin{tabular}{|ll} 
Majid & Al- \\
Taqwa & \\
\end{tabular} & Tidak ada \\
\hline & $\begin{array}{l}\text { Majid } \\
\text { Hj. Dahnia } \\
\text { Muktar }\end{array}$ & Tidak ada \\
\hline & $\begin{array}{l}\text { Masjid Al- } \\
\text { Istoqomah }\end{array}$ & Tidak ada \\
\hline & $\begin{array}{l}\text { Masjid } \\
\text { Mujahidin }\end{array}$ & Tidak ada \\
\hline & $\begin{array}{l}\text { Majid } \quad \text { Al- } \\
\text { Manar }\end{array}$ & Ada \\
\hline & $\begin{array}{l}\text { Masjid Al - } \\
\text { Muqaromah }\end{array}$ & Ada \\
\hline & $\begin{array}{l}\text { Masjid Nurul } \\
\text { Huda }\end{array}$ & Ada \\
\hline & $\begin{array}{l}\text { Mesjid } \\
\text { Jami'atul } \\
\text { Muslimin }\end{array}$ & Ada \\
\hline & $\begin{array}{l}\text { Mesjid al- } \\
\text { Ikhlas }\end{array}$ & Tidak ada \\
\hline $\begin{array}{l}\text { Sarana } \\
\text { Pendidikan }\end{array}$ & $\begin{array}{l}\text { SMP Langgar } \\
\text { Tarbiyah }\end{array}$ & Tidak ada \\
\hline \multirow[t]{3}{*}{$\begin{array}{l}\text { Tempat } \\
\text { Pemakaman } \\
\text { Umum }\end{array}$} & $\begin{array}{l}\text { TPU } \\
\text { Tanjung } \\
\text { Betung 1 }\end{array}$ & Tidak ada \\
\hline & $\begin{array}{l}\text { TPU Bandu } \\
\text { Agung }\end{array}$ & $\begin{array}{l}\text { Tidak } \\
\text { ada }\end{array}$ \\
\hline & $\begin{array}{|lr|}\text { TPU Desa } \\
\text { Simpang } \\
\end{array}$ & Tidak ada \\
\hline
\end{tabular}




\begin{tabular}{|l|l|l|}
\hline & $\begin{array}{l}\text { TPU Pancur } \\
\text { Negara }\end{array}$ & Tidak ada \\
\hline Tanah & $\begin{array}{l}\text { Tanah } \\
\text { Kosong }\end{array}$ & Tidak ada \\
\hline
\end{tabular}

Sumber: Olahan Penulis

Dalam perwakifan, nazhir adalah pihak yang menerima harta benda wakaf dari wakif untuk dikelola dan dikembangkan sesuai dengan peruntukannya.Dalam undangUndang Nomor 41 tahun 2004 tentang wakaf telah mengatur persoalan nazhir dengan sangan jelas dan rinci.Ini menunjukkan bahwa nazhir memiliki kedudukan yang signifikan di dalam undang-undang tersebut.

Eksistensi wakaf dan pemberdayaannya sangat tergantung pada nazhir.Nazhir juga berkewajiban mengerjakan segala sesuatu yang layak untuk menjaga dan mengelola harta wakaf.

Hasil penelitian menemukan bahwa tugas nazhir dalam melindungi harta wakaf sebagaimana yang diatur dalam undangundang yaitu:

\section{Peran Administrasi}

Administrasi merupakan tugas nazhir dalam hal menyelenggarakan amanah pengelolaan tanah wakaf sesuai tujuan wakif dan salah satu bentuk perlindungan harta wakaf dengan cara pembuatan akta wakaf. Berdasarkan hasil temuan bahwa manurut nazhir yang belum melalukan fungsi administrasi secara baik dan belum juga melakukan pembuatan akta wakaf dikarenakan kesibukan para nazhir yang memiliki tugas tambahan selain menjadi nazhir juga berprofesi sebagai petani maupun pejabat pemerintah seperti guru, PNS dan Kepala Desa. Nazhir lebih fokus dalam menjalankan profesi mereka, sementara menjadi nazhir hanyalah tugas tambahan dan selama ini tidak digaji, hanya menjadi amal jariah agar sarana wakaf tetap dapat dimanfaatkan oleh masyarakat.

Dalam menjalankan tugas sebagai nazhir hanya didasarkan kepada pengetahuan seadanya, tidak ada sosialisasi atau edukasi dari lembaga wakaf atau pihak pemerintah dalam memberikan pemahaman kepada nazhir dalam melakukan tugas. Bahkan sebagian nazhir tidak tahu sama sekali kalau tugas nazhir salah satunya melakukan adminsitrasi terhadap harta wakaf.

Berdasarkan temuan bahwa ada sebagian nazhir yang telah melakukan pengadminstrasian harta wakaf melalui penyusunan dan dokumen wakaf dan pembuatan akta wakaf, hal ini dilakukan karena sebelumnya terjadi sengketa harta wakaf dengan ahli waris wakif yang tidak mengakui adanya penyerahan harta wakaf oleh orang tua mereka terdahulu. Untuk mengantisipasi kemungkinan perebutan harta wakaf maka nazhir mendokumentasikan semua hal yang berkaitan dengan penyerahan harta wakaf kepada nazhir dan membuat akta wakaf agar tidak digugat oleh ahli waris atau pihak-pihak tertentu untuk memperoleh keuntungan.

Menurut pengakuan salah seorang nazhir bahwa sebaiknya para nazhir yang belum melakukan pengadminisitrasian harta wakaf, agar segera dilakukan. Karena nazhir tidak dapat memprediksi kapan sengketa tanah wakaf akan terjadi. Untuk mengantisipasi hal tersebut agar ketika harta wakaf diserahkan kepada nazhir, segera dilakukan penyusunan adminstrasi dokumen wakaf agar mudah didata dan diarsipkan untuk melindungi harta wakaf.

\section{Peran Pengelolaan dan Pengembangan Harta Wakaf}

Hasil temuan menunjukkan bahwa sebagian nazhir telah melakukan tugasnya dalam mengelola harta wakaf sebagaimana 
yang telah diamatkan oleh wakif. Nazhir menjaga dan memelihara harta wakaf agar dapat terus dimanfaatkan untuk kemaslahatan masyarakat. Seperti penggunaan harta wakaf sebagai sarana ibadah. Dengan melalukan perbaikan dan melengkapi semua fasilitas ibadah di mesjid membuat masyarakat menjadi nyaman dan dapat setiap saat beribadah ke mesjid menjadi tugas pokok nazhir bersama dengan pengelola mesjid lainnya.

Dalam pengembangan harta wakaf, nazhir belum melakukan pengembangan dengan memproduktifkan harta wakaf agar bernilai guna dan dapat dimanfaatkan secara luas oleh masyarakat. Hal ini dikarena kurangnya kemampuan nazhir dalam mengelola harta wakaf agar bernilai ekonomi dan memiliki nilai tambah dalam mensejahterakan masyarakat. Nazhir juga tidak mengetahui apabila harta wakaf boleh dikelola secara produktif, karena pemahaman selama ini nazhir hanya boleh mengelola sesaui dengan apa yang diamanahkan oleh wakif, apabila sutau tanah diperuntukkan untuk mesjid, maka nazhir hanya boleh membangun mesjid, sisa tanah atau lingukngan mesjid tidak boleh dibangunkan tempat yang bernilai komersil karena ini tanah wakah, walaupun posisi tanah wakaf dekat dengan lingkungan penduduk, pinggir jalan dan bahkan dekat dengan pasar. Namun sifat kehati-hatian nazhir, tidak berani untuk melakukan pengelolaan lingkungan tanah wakaf untuk pengembangan ekonomi.

Berdasarkan hasil temuan didapat lima harta wakaf yang memiliki potensi untuk dikebangkan secara produktif seperti mesjid Jamiatul Muslimin, Mesjid Mujadihin, Mesjid al-Muqaromah, SMP Langgar Tarbiyah dan satu lahan kosong yang belum dibangun sarana untuk kepentingan masyarakat. Kelima sarana ibadah, dan sarana pendidikan serta lahan kosong dapat menjadi lahan produktif, karena sisa tanah setelah dibangun bangunan mesjid dan sekolah masih sangat luas. Posisi tanah wakaf yang berada di tengah-tengah pemukaman masyarakat, dan pinggir jalan sangat produktif bila dimanfaatkan dan dikelola secara baik, maka akan memberi nilai tambah bagi pengembangan harta wakaf.

Hasil dari pengelolaan harta wakaf dapat membantu ekonomi masyarakat sekitar, melalui penyewaan tempat untuk berdagang atau dikelola dengan membangun toko yang dapat dikelola nazhir sebagai pemasukan dari pengelolaan tanah wakaf. Selain itu dana yang diperoleh dari pengelolaan dan pengembangan wakaf dapat dimanfaatkan untuk pemeliharaan harta wakaf berupa mesjid atau sekolah. Pengurus mesjid tidak khawatir mencari dana untuk pemeliharaan harta wakaf, karena dapat diperoleh dari pengelolaan produktif tanah wakaf.

Nazhir diharapkan memiliki jiwa interprenership dan pemahaman fikih wakaf dalam hal pengembangan wakaf. Karena ada sebagian pemahaman nazhir bahwa harta wakaf tidak boleh dijadikan sebagai alat untuk memperoleh ekonomi atau dikomersilkan, harta wakaf hanya boleh dimanfaatkan untuk ibadah atau kegiatan sosial lainnya, karena pemanfaatan wakaf di luar yang diamanahkan wakif dianggap menyalahkan pengelolaan wakaf oleh nazhir.

Berdasarkan pasal 42 dan 43 Undangundang wakaf, nazhir bertanggung jawab untuk mengelola harta wakaf sesuai dengan prinsip syariah dan diproduktifkan melalui lembaga penjamin syariah. Hal ini dilakukan guna memberikan jaminan harta wakaf agar ketika dilakukan pengelolaan yang bersifat produktif pokok harta wakaf tidak berkurang nilai dan akan terjaga dari kerusakan dan pengurangan nilai poko wakaf.

Nazhir dalam pengelolaan dan pengembangan harta wakaf tidak boleh 
melakukan perubahan peruntukan harta wakaf kecuali dengan izin Badan Wakaf Indonesia (BWI) sebagaimana yang diatur dalam pasal 44 Undang-undang wakaf.

\section{Peran Pengawasan dan Perlindungan Harta Wakaf}

Nazhir memiliki tugas untuk melakukan pengawasan dan perlindungan harta wakaf dengan memastikan kalau pokok harta wakaf tidak berkurang nilanya, tidak dijual, diwariskan atau dihibahkan. Dalam melindungi harta wakaf nazhir melakukan pembuatan bukti harta wakaf dalam bentuk akta ikrar wakaf dan membuat pengukuran batas tanah dilengkapi dengan tanda ukuran tanah, agar terjaga kuantitas tanah wakaf.

Berdasarkan hasil temuan bahwa nazhir sudah melakukan pengawasan dan perlindungan harta wakaf melalui pembuatan pagar atau batas tanah agar tidak diambil oleh masyarakat. Selain itu nazhir juga melakukan pengawasan terhadap kondisi lingkungan tanah wakaf agar bersih dan terpelihara bangunan dan tanamannya. Hal ini dilukan sebagai bentuk pengawasan dan perlindungan harta wakaf, walaupun ada sebagian nazhir yang tidak membuat patok ukuran tanah, seperti tanah wakaf dibiarkan saja sejak tanah diwakafkan karena diyakini tidak akan diambil oleh masyarakat sekitar karena hampir sekeliling tanah wakaf sudah berisi makam, hal ini dianggap batas dari tanah wakaf.

\section{Peran Pelaporan ke BWI}

Berdasarkan hasil wawancara terhadap 18 nazhir ditemukan bahwa tidak ada nazhir yang mengetahui Badan Wakaf Indonesia, baik tugas dan fungsinya, posisi dan kantornya. Bahkan ada yang baru pertama kali mendengar istilah BWI. Hal ini dapat difahami karena memang belum ada sosialisasi baik dari pemerintah maupun BWI sendiri yang turun langsung ke lapangan untuk melakukan sosialiasasi kepada masyarakat tentang keberadaan lembaga ini, tugas dan fungsinya. Hal ini menjadi perhatian penting guna memberikan pemahaman bagi masyarakat tentang peran nazhir yang harus melakukan tugas mereka untuk menyampaikan laporan pelaksanaan pengelolaan harta wakaf.

Harta wakaf pada dasarnya adalah miliki bersama, begitu juga pemanfaatannya harus dapat dirasakan oleh umat muslim. Secara ideal pengelolaan harta wakaf merupakan tanggungjawab kolektif untuk menjaga eksistensinya. Keberadaan lembaga yang mengurusi harta wakaf mutlak dilakukan sebagaimana yang dilakukan oleh negara muslim lainnya di dunia. Indonesia masih terkesan lamban untuk mengelola harta wakaf meskinpun mayoritas penduduknya adalah muslim. Implikasi dari lambannya pengelolaan wakaf, banyak harta wakaf yang tidak terurus bahkan belum dimanfaatkan. (Qodin, 2014: 37-54)

Ketika harta wakaf telah diserahkan wakif kepada nazhir, maka nazhir memiliki tanggungjawab untuk melakukan pengelolaan dan pengadministrasian harta wakaf dan memanfaatkan tanah wakaf sebagaimana yang telah diamanahkan untuk dikelola demi kepentingan masyarakat. Karena itu jabatan nazhir harus diberikan kepada seseorang atau lembaga yang mampu mengelolanya.

\section{KESIMPULAN}

Pelindungan harta wakaf menjadi tugas nazhir yang harud dijalankan dengan melalukan pengadmistrasian, pengelolaan, pengembangan dan melaporkan pelaksanaannya kepada Badan Wakaf Indonesia.

Banyak nazhir yang belum memahami secara jelas tugas dan tanggung jawab nazhir dalam memberikan perlindungan harta wakaf, 
hanya sebagian yang telah memiliki akta ikrar wakaf sementara lainnya belum ada. Bila kondisi ini dibiarkan akan menyebabkan harta wakaf akan berkurang nilainya bahkan dapat diambil kembali oleh ahli waris bila tidak dilengkapi oleh Akta Ikrar Wakaf sebagai bentuk perlindungan harta wakaf.

Pemerintah dan Badan Wakaf Indonesia diharapkan melalukan sosialisasi dan edukasi kepada masyarakat tentang keberadaan BWI, tugas dan fungsi nazhir dalam pengeloalan harta wakaf serta memberikan pemahaman kepada nazhir tentang fikih wakaf dan mengembangkan jiwa interprenership agar harta wakaf dapat dikelola secara produktif dan memberi nilai tambah bagi perkembangan ekonomi masyarakat sekitar tanah wakaf.

Peran nazhir yang dapat mengelola wakaf secara profesional dapat membantu pengembangan harta wakaf agar memiliki nilai harta wakaf yang terus bertambah dan berkembangkan dan dapat dijadikan sebagai pemeliharaan dan mobilisasi harta wakaf agar kualitas dan kuantutasnya tidak berkurang, sehingga dapat memeberi nilai manfaat yang besar bagi masyarakat.

\section{DAFTAR KEPUSTAKAAN}

Abdul Halim. 2005. Hukum Perwakafan di Indonesia. Ciputat Press.

Afdi, Muhammad, N. 2017. Development of Productive Waqf in Indonesia: Potential and Problems. Munich Personal RePEc Archive, 97967,. https://mpra.ub.unimuenchen.de/id/eprint/97967

Aziz, M. 2017. Peran Badan Wakaf Indonesia (BWI) Dalam Mengembangkan Prospek Wakaf Uang Di Indonesia. JES (Jurnal Ekonomi Syariah), 2(1), https://doi.org/10.30736/jesa.v2i1.14

Departemen Agama RI. 2005. Naz̧bir Profesional dan Amanah. Ikhlas Beramal.
Fadhilah, N. 2011. Sengketa Tanah Wakaf Dan Strategi Penyelesaiannya. Journal de Jure, 3(1) . https://doi.org/10.18860/jfsh.v3i1.1321

Junaidi Abdullah dan Nur Qodin. 2014. Penyelesaian Sengketa Wakaf Dalam Hukum Positif. ZISWAF: Jurnal Zakat Dan Wakaf, 1(1).

Kasdi, A. 2014. Peran Nadzir Dalam Pengembangan Wakaf. Jurnal Zakat Dan Wakaf, 1(2), 213-226.

Megawati, D. 2014. Pengelolaan Dan Pengembangan Wakaf Produktif Di Kota Pekanbaru. Hukum Islam, XIV(1).

Ridwan, M. 2012. Naz̧bir Profesional Kunci Kesuksesan Wakaf Produktif. Muqtasid: Jurnal Ekonomi Dan Perbankan Syariah,3(1).https://doi.org/10.18326/m uqtasid.v3i1.91-109

Risca Putri Prasinanda, T. W. 2019. Peran Nazhir dalam Mengelola Hasil Wakaf Uang pada Badan Wakaf Indonesia Jawa Timur. Jurnal Ekonomi Syariah Teori Dan Terapan, 6(12). https://media.neliti.com/media/publicati ons $/ 315161$

Sugiyono. 2014. Memahami Penelitian Kualitatif. Alfabeta.

Tiswarni. 2014. Peran Nazhir Dalam Pemberdayaan Wakaf (Tinjauan Terbadap Strategi Pemberdayaan Wakaf Badan Wakaf Alquran Dan Wakaf Center). Al-'Adalah, $\mathrm{XII}(2)$.

Wulandari, S., Effendi, J., \& Saptono, I. T. 2019. Pemilihan Naz̧bir Dalam Optimalisasi Pengelolaan Wakaf Uang. Jurnal Aplikasi Bisnis Dan Manajemen, 5(2).https://doi.org/10.17358/jabm.5.2.2 95

Terapan, $\quad 6(12)$, 2553-2567. https://media.neliti.com/media/publicati ons $/ 315161$ 